\title{
Соціологія
}

DOI: $10.15421 / 172060$

УДК: 316.332

\section{Class transition: a life in between}

\section{Oksana Burak, Univertsity of Vienna Institute for Sociology}

An individual must always be considered in the context of a "collective memory" because he always belongs to several groups, either simultaneously or consecutively. Sometimes these groups overlap, they develop and are constantly in motion". Didier Eribon

The author would like to thank Prof. Dr. Christof Reinprecht for the inspiration and his essential contribution in her sociological formation with the seminar "OriginDeconstruction of a sociological category".

Most scholars within sociology of education focus on the reproductive function of the education system and on inequalities related to it. Rarely attention is paid to cases which don't reproduce the class of origin. In particularly to the circumstances under which the class-crossers succeed to make an upward transition and to their life after they enter the upper class. However even P. Bourdieu has actually searched for the mechanisms that could prevent reproduction of social inequality by means of education. This topic remains relevant also in the modern time of (un)equal access to the educational institutions. The problem of reconstruction of exiting social order by educational systems has been not solved yet. It would notably contribute to the reduction of social inequality if we could reconstruct the pattern, that promote/hinder social mobility during the education path. In this article, we analyze the class transition experience of P. Bourdieu and D. Eribon based on their self-analysis and try to integrate a new non-reproduction approach of C. Jaquet in this pattern of social mobility through the education. On the basis of the autobiographical life-stories of mentioned above two sociologists we try to reconstruct the main driving force that has enabled them the way up und also to determine how the life of a class-crosser looks after they succeed the transition. After analyzing the work of P. Bourdieu named "Ein soziologischer Selbstversuch" and the work of D. Eribon named "Rückkehr nach Reim" we could confirm an assumption of C. Jaquet that ambition is the most powerful driving force for social mobility. Moreover, we can conclude that not only a person can be willing to leave the milieu of origin, but that he/she can be just displaced by the milieu. In such a situation he/she is a refugee and is forced to flee. In the most cases of escape and desire to climb up the social ladder such "negative" feelings as shame play a role of a driving force. Besides, the fact of social mobility is usually regarded as an end destination when in fact this transition is a process that never ends but transmutes in new forms.

Keywords: class-crosser, split identity, social reproduction, inequality, non-reproduction, complexion, origin, affect, social mobility 


\section{Міжкласова мобільність: життя на рубежах}

\section{Оксана Бурак, Інститут соціології Відентського університету}

Більшість науковців соціології освіти займаються дослідженням репродуктивної функції освітньої системи та соціальної нерівності, яка безпосередньо з нею повязана. Набагато рідше звертається увага на випадки, в яких особистість не репродукує клас свого походження, коли їй вдається перетнути межу і увійти до класу вищого, ніж клас ії походження, підвищити свій соціальний статус. Сам П. Бурд’є, який зробив досить суттєвий внесок саме в теорію репродукції, насправді намагався знайти механізми, які б допомогли мінімізувати вплив системи освіти на репродукцію соціальної нерівності. Ця тема залишається актуальною до сьогодні, коли начебто кожен має рівне право доступу до послуг освітньої системи і відповідно рівні шанси соціальної мобільності. Однак проблема нерівності в освіті залишається невирішеною і тому актуальною. Реконструкція схеми, яка уможливлює/перешкоджає індивіду досягти вищого соціального статусу завдяки освіті, значно б допомогла на шляху мінімізації соціальної нерівності. У цій статті ми аналізуємо досвід соціальної мобільності П. Бурдьє та Д. Ерібона на основі їхніх текстів самоаналізу та намагаємось інтегрувати новий підхід «нерепродукції» Ш. Жаке в цю модель зміни соціального статусу. На основі автобіографічних історій згаданих вище соціологів ми намагаємось реконструювати головну рушійну силу, яка дозволила їм подолати шлях з нижчого до вищого соціального класу, а також визначити, як виглядає життя «дезертирів» після такого транзиту.

Проаналізувавши життєві історії П. Бурдьє та Д. Ерібона, ми змогли підтвердити припущення Ш. Жаке про те, що найпотужнішою рушійною силою соціальної мобільності є амбіція - одна зі складових описаного нею комплексу афектів. Більше того, ми можемо зробити висновок, що не тільки індивід може хотіти залишити клас свого походження, але і що він може бути просто витіснений самим цим класом. У цьому випадку він $є$ біженцем і змушений мігрувати. У більшості випадків міграції до вищого класу такі «негативні» почуття, як сором, грають роль рушійної сили. Крім того, часто ці випадки соціальної мобільності, сприймаються як кінцева ціль, як «хеппі енд». Насправді цей перехід - це не просто факт, а процес, який ніколи не закінчується і просто набуває нових форм.

Ключові слова: подвійна ідентичність, сочіальна мобільність, міжкласовий «дезертир», соціальна нерівність, соиіальна (не)репродукція, «комплекиія», аффект, походження

\section{Межклассовая мобильность: жизнь на рубежах}

\section{Оксана Бурак, Институт социологии Венского университета}

Большинство ученых социологии образования занимаются исследованием репродуктивной функции образовательной системы и социального неравенства, непосредственно с ней связанной. Гораздо реже обращается внимание на случаи, в которых личность не репродуцирует класс своего происхождения, когда ей удается пересечь границу и войти в класс выше, чем класс ее происхождения, повысить свой социальный статус. Сам П. Бурдье, который сделал достаточно существенный вклад именно в теорию репродукции, на самом деле пытался найти механизмы, которые бы помогли минимизировать влияние системы образования на репродукцию социального неравенства. Эта тема остается актуальной до сих пор, когда вроде каждый имеет равное право доступа к услугам образовательной системы и соответственно равные шансы социальной мобильности. Однако проблема неравенства в образовании остается нерешенной и поэтому актуальной. Реконструкция схемы, делает/препятствует индивиду достичь высокого социального статуса благодаря образованию, значительно помогла на пути минимизации социального неравенства. В этой статье мы анализируем опыт социальной мобильности П. Бурдье и Д. Эрибона на основе их текстов самоанализа и пытаемся интегрировать новый подход «нерепродукции» Ш. Жаке в эту модель изменения социального статуса. На основе автобиографических историй упомянутых выше социологов мы пытаемся реконструировать главную движущую силу, которая позволила им преодолеть 
путь из низшего к высшему социальному классу, а также определить, как выглядит жизнь «дезертиров» после такого транзита.

Проанализировав жизненные истории П. Бурдье и Д. Эрибона, мы смогли подтвердить предположение Ш. Жаке о том, что самой мощной движущей силой социальной мобильности является амбиция одна из составляющих описанного ею комплекса аффектов. Более того, мы можем сделать вывод, что не только индивид может хотеть покинуть класс своего происхождения, но и он может быть просто вытеснен самим этим классом. В этом случае он является беженцем и вынужден мигрировать. В большинстве случаев миграции к высшему классу такие «отрицательные» чувства, как стыд, играют роль движущей силы. Кроме того, часто эти случаи социальной мобильности, воспринимаются как конечная цель, как «Хэппи энд». На самом деле этот переход - это не просто факт, а процесс, который никогда не заканчивается и просто приобретает новые формы.

Ключевые слова: двойная идентичность, социальная мобильность, межклассовый «дезертир», социильное неравенство, социиальная (не)репродукция, «комплекция», аффект, происхождения

\section{Introduction}

7 he topic of social mobility through educational institutions and the role of the last in the modern society as a powerful agent of social structure stays to be controversial and doesn't lose its relevance also in modern society that seems to provide equal access to education for every member of society. The research in the field of sociology of education began in the middle of the19th century with the work of E. Durkheim on moral education and with the M. Weber's Chinese literati. After World War II, with industrialization and democratization of society when the education system started to opened its doors for all, the interest in the field of education in sociology has increase. Different theoretical perspectives have appeared. The Political Arithmetic tradition (Hogben, 1938) in Great Britain which had more quantitative character and dealt with social inequality based on the research about the place of school structure in social class inequalities issues. Later this approach was criticized because of its quantitative intention. The tradition of structural functionalism had the functions of education in scope. The followers of this tradition tried to crystalize some groups of functions. According to this tradition there were some manifest functions of education like to provide the possibility of upward mobility and the chances of good career and success for students. Latent functions dealt more with socialization of individuum. At the later stage the functionalists payed attention also to the inequality in education. R. Meighan agrees, stating that large numbers of capable students from working-class backgrounds fail to achieve satisfactory standards in school and therefore fail to obtain the status they deserve (Meighan, \& Siraj-Blatchford, 1997, p. 143). M. Sargent confirms this arguing that schooling supports continuity, which in turn supports social order (Sargent, 1994, p. 201). The purpose of educational system to maintain social inequality was also widely discussed in the frame of conflict theory. According to conflict theorists the reproduction of social inequality occurs because of ideology provided by the dominant group and the fact that education is available to all is a myth. Moreover, the system blames an individual in case he/she doesn't archive a success (Sargend, 1994, p. 84). This perspective has been criticized as deterministic and pessimistic, while there is some evidence for social mobility among disadvantaged students (Kislev, 2016). This reproductive function of educational system has been theorized by P. Bourdieu in connection with class inequalities and cultural capital. However, in this article will be discussed not only his theoretical ideas but also his own experience from his own words will be analyzed. In order to compare and to make some conclusions about some consistent patterns in this respect an educational path of D. Eribon which he explicated in such works as "Retour a Reims" and "La société comme verdict. Classes, identités, trajectoires" will be also an object of analysis. But the most important aim of this article is to integrate a new approach of C. Jaquet of non-reproduction in the theory of social reproduction based on the sociological self-analysis of mentioned above sociologists. Besides, it is aimed to analyze how the life of class-crossers changes when they pass from the class of ruled in the class of rulers: where and when this transition ends up. 
It has been written a lot about social inequality that is reproduced through the educational system but as also E. Kislev noted there are some evidence of upward mobility among disadvantaged students and C. Jaquet tries to explain and theorize e this phenomenon which is also to be seen in the life of Bourdieu and Eribon but which were not explained enough from themselves. They succeed an upward mobility in spite of their disadvantaged start position and origin but what helped them to do so? Are there some patterns on the way of class-crossers? C. Jaquet tries to answer this question and thereby to cover the blanks in the theory of reproduction.

\section{Institutional Dimension}

A decisive criterion of class transition or social advancement is education. An increasing social mobility without legitimate proof from the educational institutions is hardly possible and to get this recognition through the education is a great challenge caused by social structure. That is the reason why this topic has been widely discussed in works also of such sociologists as P. Bourdieu and D. Eribon. The experience of both authors who crossed the class borders though the education is a relevant subject for sociological analysis.

Bourdieu describes the difficulties that have him so overwhelmed, on the one hand, in the form of teachers' unlimited power, which the institution confers on them (Bourdieu, 2002, p. 108) and, on the other hand, in the form of violence in relations among the pupils, which often took the form of a class racism (Bourdieu, 2002, p. 111). He tells a story that he often experienced with one of the classmates. This boy often hurt Bourdieu by pronouncing his name like the farmer's one or by making fun of the name of his home village (Bourdieu, 2002, p. 111).

He felt a discrepancy between high academic recognition (because he was successful) and a lower social background. This caused the feeling of divided habitus marked by tension and contradictions. This point undoubtedly contributed to his contradictory relationship with school. It was a mixture of rebellion and conquest, distancing and self-defense (Bourdieu, 2002, p. 113). As C. Jaquet claims, it is not about fix placing in a new milieu but just a finding of a right distance between two of them (Jaquet, 2018, p. 147).
Just as Bourdieu, Eribon was an excellent student. But he was also impudent and disrespectful to his teachers" and "often doubled his sarcasm and vulgarity" (Eribon, 2016, p. 151). It was probably a protective reaction against failure, against other children who already knew a lot of stuff and took many things for granted and against teachers who tried to sanction the difference. An example could be a language: Eribon writes that it is more a game with the linguistic levels, with milieuand situation-specific registers (Eribon, 2016, p. 99) and that he found it difficult to improve pronunciation and adapt his self-expression to new academic style. Music lessons were also a real challenge for him: the question was whether certain pieces were familiar and understandable or unfamiliar to one (Eribon, 2016, p. 160). Eribon had no competence in this field and hid this under sarcasm and disobedience. Interest in art or literature was also a matter of access to such things outside the school or even before the school. It was a reason for distinction and exclusion if you were a stranger in this area. Although such a challenge intimidated Eribon, he did everything to become like "these people" (Eribon, 2016, p. 98). According to Jaquet it is a positive effect of an intensive feelings of anger, hate and shame which make one not to give up, to become an opposite value in order to replace these unpleasant feelings (Jaquet, 2018, p. 75). The following phrase demonstrate which traces the whole thing has left in Eribon's selfperception: "I am a product of insult, a son of shame." (Eribon, 2016, p. 194). One can hardly imagine what kind of strength one needs to go on in this situation and not to give up. In this case an obstacle turns into an advantage. The bigger the obstacle is, the bigger is also the wish to overcome it (Jaquet, 2018, p. 31). If one assumes that one affect can only be defeated by another contra effect which is stronger than the first one, then a great shame can be dispelled by a great pride (author: success for example) (Jaquet, 2018, p. 189).

The phenomenon of continuous social transformation that has become a theme in the works of Bourdieu and Eribon is probably experienced by each member of society in his own way. Social mobility would not have been possible otherwise. Regardless of the extent and nature of the transition, "defectors" share similar feelings and face a number of similar 
difficulties. A transition is always painful. The individual stands between the worlds, in a vacuum and between two poles each of which attracts him to itself. One is in the middle of nowhere and it is a time of metamorphosis and transformation. It is the time when the individual is not aware of his own habitus, which he perceives "through the observations of other people". One flees to the "better world" but the price is high. One has to fight and only when he is sure of his goal, he doesn't give up and tries to overcome the obstacles on the way. Eribon speaks of "re-education", which one has to go through in order to be able to move vertically, to enter another world, another social class (Eribon, 2016, p. 93).

\section{Initiation in a new world}

Eribon describes the time of adaptation to the culture of school and learning as a long and chaotic process and speaks of physical and mental discipline, which is not something innate and for which one needs time and patience (Eribon, 2016, p. 158). One had to unlearn what he had originally been. He had to work on the things that were self-evident to others, day after day, month after month. Eribon points out that the whole process changed his habitus and personality from the ground up. Bourdieu explains the painfulness of this process with the argumentation, that it is a physical learning through the body (Jaquet, 2018, p. 131). One should appropriate a new behavior model, transform old values, relearn a language and it can bring to overtaxing. It means to bend one's body and mind to constraints that oppose and contradict the established habits to such an extent that the acquisition of a new attitude can become a torture (Jaquet, 2018, p. 131). Besides, there is no guarantee that sometimes it will be over: "It is not easy to describe this double movement between two worlds: one discovers that one is different, one tries to organize one's life according to this otherness and to shape oneself according to it: At the same time, however, one recognizes that this new identity is something shameful that can only be lived in the sign of fear". (Eribon, 2017, p. 47).

The question is why a person wants to change the environment where he/she lives? Behind this is necessarily a desire to escape or a search for something better, which in the end makes you flee again. The trigger is usually a certain dissatisfaction with the condition of the things that one has. This dissatisfaction should be strong enough to make one decide to take a risk. One can assume that the reason could be a wish of better life and that is the decision only of the class-crossers. But Jaquet supposes that a classcrosser could be forced to do this step because his native milieu rejects him and ejects him as a foreign element with the aim to maintain its own order (Jaquet, 2018, p. 80). The potential classcrosser has just no place there any more, he is a black sheep, he is superfluous and must migrate as he has no acceptance in the native class but instead ignorance and contempt (Jaquet, 2018, p. 81). The reason can be quite different. In the case of Eribon it was his homosexuality which could be not accepted in his milieu in any case. He had to go away, he had no other choice and he wanted to take revenge on fate.

Eribon describes his integration into the higher school as exile. He had to break away from his family and social ties and learn to live differently (Eribon, 2016, p. 191). To keep these two spheres together, to belong to both at the same time, was practically impossible. "It was a split between my two personalities" (Eribon, 2016, p. 159) writes Eribon. He felt himself "terrorized" (Eribon, 2016, p. 194). It seemed to him as if everyone knew who he really was and that he wanted to hide something. He describes himself as a defector and his path as the path of a climber (Eribon, 2016, p. 23). In his decision to leave the city of his birth and adolescence he sees a chance to live as he wants (Eribon, 2016, p. 20). He had to leave Harlem behind him if he wanted to become a writer first of all (Eribon, 2016 , p. 29). He was full of hopes and ideas about his future life in Paris. Unfortunately, the reality was different than he had dreamed. The in-between space was not easy for him to survive. "I had to fight, first and foremost against myself, to be granted opportunities and rights that were given to others from the beginning" (Eribon, 2016, p. 229). "The position that I reached in the mid-nineties, was granted to others much earlier in life" (Eribon, 2016, p. 320). This is about the capital that the others already had. They were already networked, they were familiar with the environment and ways of dealing with it on the unconscious level, they used the resources of their families, and in this case, one has to make multiple efforts to find his way and continue to get along, even to be ahead of others. 
Bourdieu also felt himself alienated between these two worlds and their irreconcilable values (Bourdieu, 2002, p. 112). He interprets a split habitus as the result of a reconciliation of opposites (Bourdieu, 2002, p. 116). This dual experience reinforced the clear discrepancy between high academic recognition and a lower social background, and thus a split habitus dominated by tensions and contradictions. Like Eribon, he describes the Gymnasium in black, as a place full of betrayal and loneliness, where there is no peace. He describes the world of the boarding school as immense and terrible school of reality, where one always feels in need of survival (Bourdieu, 2002, p. 103). The whole thing often brought him to tears, because he felt hopeless, without anyone to complain to about his suffering (Bourdieu, 2002, p. 104). Bourdieu compares life in boarding school with the total institutions of Goffman (Bourdieu, 2002, p. 105).

But at the same time, in his work of selfanalysis, he recounts how he felt at home, that he could not enjoy the holidays because he felt himself miserable also there. For the local people he was a "misery" who attends a secondary school. That made him the outside. Life at home was boring for him without the school things he got used to. He also felt lonely because he could no longer share anything with his old comrades from primary school (Bourdieu, 2002, p. 106). He was 12 and had no one whom he could trust or who could understand him: "Never was the loneliness as great as at those moments" (Bourdieu, 2002, p. 107). In this case he was just displaced within his own class.

To sum up, it can be said that the transition never takes place without sacrifice. Moreover, one has to accept life between two worlds, in a space between, and cope with a split habitus continuously: "He could not find a new paradise and the old one was not reachable anymore"(London, 1927, p. 266).

\section{Split identity}

The class-crosser is characterized by a double affiliation: he is in the midst of the milieus, but also at their point of contact, in the space in between (Jaquet, 2018, p. 135). At the point of contact of two worlds he experiences a double distance, namely to the milieu of origin and the milieu of arrival (Jaquet, 2018, p. 138). His life is a constant back and forth.

Jaquet claims that this distance, especially to the milieu of origin, is more mental than spatial (Jaquet 2018, p. 139). Although the parting is very often about a change of place, precisely because the two worlds cannot coexist in the same space and on the same playing field. Therefore, historically, class change has been characterized also by a geographical separation such as crossing a border, city and country, capital and province, center and periphery, suburbs and dormitory towns, developed countries and developing countries ... (Jaquet, 2018, p. 141).

There is also a time dimension represented in such stages as the separation from the family of origin, the adaptation to a new way of life or the ascent in the arrival milieu, and this is not a linear progress; it is a mixture of flows and back flows, in which the past returns in the present. In this process, many things change about the person and there will never be a pure color, but a mixture of their shades. So, class-crosser is to think like a being that forms a knot of relationships and affects that are combined to produce a reconfiguration (Eribon, 2016 , p. 101). His life path is often a chaotic hybridization, which is why his identity never becomes homogeneous.

There are different layers in this hybridization that also are expressed and felt differently. The intellectual layer and the layer of higher international culture can be modified more easily, but the layer of national culture and identity, national values and national character (the religious aspect also plays a role) is much more difficult to uproot. It is something different, something that lies at the core of personality and that one becomes with the mother's milk, and without that you "lose" yourself and always circle somewhere else, but again and again you can't find peace. National identity and cultural values are like a harbor where you hold the anchor.

The phantom of the world of origin and selfperception

It is difficult for the person to grasp and define the double habitus. It can lead to confusion, that is in its turn expressed in behavior and reactions. For example, Bourdieu reports constant difficulties at school because of his "bad behavior," and wonders whether it was probably his own fault, whether he himself was the cause of all these difficulties, which were defined as "his bad character" (Bourdieu, 2002, p. 106). This is probably 
why he also describes his success at school as "unexpected", because he judged himself by how others perceived his behavior. He was described as "stubborn" and punished, but again he reacted to this with anger and confrontation.

Bourdieu reports in his self-analysis also about a feeling of guilt. This feeling arose from the betrayal of his origins, because very often in academic settings he was confronted with statements that insulted the people to whom he actually belonged, but he couldn't do anything about it because he didn't want to unmask himself. It was a mix of the feeling of shame with the feeling of guilt (because of the betrayal). He describes this mixture as if he "had to walk on coals" (Bourdieu, 2002, p. 114).

The same can be found in Eribon's work, where he says that he always had to deny his real identity. He calls his life a "social cupboard" because he always concealed his homosexuality and origin (Eribon, 2016, p. 20). He felt shame not only because of his sexual orientation but also because of his origin at the same time. This is expressed in his description of own brother, whose manners, posture showed that he belonged to a lower social class: "If anyone asked me about him, I was always terribly embarrassed, and I tried to distract from the subject" (Eribon, 2016, p. 101). He writes that his origin was for him a mixture of disgust and hatred (Eribon, 2016, p. 13).

It should also be noted that no matter how strong the desire of transition or hatred for the milieu of origin is, you can never get rid of your past and habitus embodied from birth. Classcrossers are always tied to their origin, whether they are aware of it or not. The bond of origin cannot be completely severed. Integration into another world does not know a point from which there is no turning back, because we are always referred to our origin, even if only at the moment when the death of our parents reminds us of it (Eribon, 2016, p. 135).

Eribon reports that he sent the letters home from time to time and describes the thoughts he had at that moment: "When writing the address, I wondered what the place where they lived looked like. I never pushed my curiosity further. When I had them on the phone three or four times a semester, often less frequently, my mother would ask me: when are you coming to visit us? I pretended to be very busy and promised to come soon. But I hadn't planned to. I had fled from my family and did not feel the slightest desire to see them again" (Eribon, 2016, p. 9). Nevertheless, looking at the old photos in the album with his mother after his father's death, regretting that he did not try to talk to him before. It is difficult for the classcrossers to forget people that they left behind and who provided them a platform to start (Jaquet, 2018, p. 198).

In addition, the same rule applied to Eribon as to Bourdieu: he felt hatred when people in his environment spoke contemptuously or disrespectfully of the "vulgar people". They were in the end people from whom he originally came (Eribon, 2016, p. 23). He was tormented by his conscience but could not do anything about it (Eribon, 2016, p. 25). There it is exactly about the "split habitus" which he also mentions in his work. Although he wanted to finally free himself from his milieu, he does not succeed. He could not get rid of these embodied feelings of belonging to it. That is why he constantly felt himself as an insider and as a strange at the same time in the place where he lived. He confesses that this balancing has become almost impossible for him over the years (Eribon, 2016, p. 25).

Social origin versus homosexuality in selfanalysis

Both of the authors (Bourdieu and Eribon) in their self-analyses have dealt with the question of homosexual identity, leaving the issue of social origin more in the dark. They question the reason of it also themselves: "Why me, who were ashamed of his origin and either lied about it to people from other social classes that I met in Paris or confessed about it with the great embarrassment, so why did I never think of writing about this problem in a book or an essay?" (Eribon, 2016, p. 19). He answers the question himself: "It was easier for me to write about sexual shame than about social one" (Eribon, 2016, p. 19).

Eribon also critically questions Bourdieu's self-analysis. He seeks answers to the following questions (Eribon, 2016, p. 153-154): Why did the will to ascend triumph over his feeling of non-conformity? How did he get along with all these tensions and contradictions? How did he manage to overcome the difficulties and keep himself in a universe that he actually totally rejected but that he did not want to leave under any circumstances? He wonders why Bourdieu 
didn't say something about the books he read, about the people who were important to him, who gave him a taste of this high culture, how people with whom he shared his environment before, who came from the same milieu, disappeared from his life and those who remained, for what reasons did they remain? How was the whole transformation possible? And how exactly did it happen?

It is interesting how Eribon reflects on his homosexuality. In his analysis of homosexuality, he refers back to his relationship with his father. $\mathrm{He}$ reports that he experienced his father's aggressive behavior like a nightmare and that probably the father himself was a reason for his homosexuality (Eribon, 2016, p. 88): "The horror that gripped me at that time did not come from the person acting, but from the social environment that made such actions possible. The scene with the bottles (author: which the father smashed against the wall) lasted only a few minutes but it burned me with a revulsion against my misery, with a rebellion against my social fate. It left the hidden but always painful wound in my everlasting memory" (Eribon, 2016, p. 90).

Probably the both authors associated their homosexuality with their experiences on early socialization stage which was not easy for them and played a dominant role. Besides, they had to leave the milieu and feel shame and guilt because their sexual orientation could be not accepted in their class of origin. The root course of their escape lies deep in their social origin and homosexuality is only one of the upper layers of the complex problem.

\section{Conclusions}

Both Bourdieu and Eribon in their selfreflections tried to understand and explain the process of social upward mobility / class transition for people from disadvantaged social classes from the perspective of social structure which (according to them) is responsible for the reproduction of inequalities. They describe the obstacles that stood in their way and the metamorphoses they experienced in the space in between. They paid for it with the life of misery, with life in the social cupboard, with the split habitus, with life in shame and constant fear. This was a successful attempt to discover the dimensions of judgement of social system in order to find a perspective that could help to overcome produced by the system obstacles.
Bourdieu has actually never seen the social reproduction as a fate or law notwithstanding that he has developed it. His aim was to understand the social determinants of judgement, in order to gain instruments that would help one to detach from them (Jaquet, 2018 , p. 13). The attempt of C. Jaquet is a further step to develop this intention of Bourdieu. She tried to reconstruct patterns and mechanisms which help the class-crosses in the process of class transition. She proposes a new concept of "complextion" Complexion is the chain of determinations that link together to form the texture of a singular life (Jaquet, p. 101). The class-crosser in its turn is a being that forms a node of relationships and affects that are combined and composed to produce a new reconfiguration of a person (Jaquet, 2018, p. 131). Affects are physical and mental modifications, that touch, move and excite us (Jaquet, 2018, p. 67). According to Jaquet the most influential affect is ambition. It is an engine of non-reproduction and social upward mobility (Jaquet, 2018, p. 31). The driving force of ambition is the desire to surpass oneself (Jaquet, 2018, p. 33). This is not a careerism, but an expression of the desire to live, the appetite for life and self-affirmation (Jaquet, 2018, p. 34). One can suppose that there are people who have ambition and who do not have them naturally. Jaquet claims that ambition is not something given from the birth but a cognitive determination formed by affects (Jaquet, 2018, p. 36). It was the force that moved Bourdieu and Eribon like also other class-crossers. An empirical (qualitative) reconstruction of affects on the examples of the certain cases of social upwards mobility would be a relevant perspective for the further research concerning the issue.

Another conclusion to be made is the fact, that the way of class-crossing doesn't finish with entering new class but instead never ends. The class-crosser remains a survivor, an anomality or an exotic curiosity (Jaquet, 2018, p. 148). He/ she is not firmly in the saddle, his/her place is only on credit (Jaquet, 2018, p. 149). Based on this it can be said that social upward mobility is not only an elevation. It happens in almost direct proportion to the latent losses. The life way of the class-crosses after their entering an upper class could be also a subject for the further research. 


\section{REFERENCES}

Bourdieu, P. (2002). Ein soziologischer Selbstversuch. Frankfurt am Main, Suhrkamp.

Bourdieu, P., \& Passeron, J. C. (1988). Die Illusion der Chansengleichheit. Stuttgart.

Eribon, D. (2016). Rückkehr nach Reim. Berlin.

Eribon, D. (2017). Gesellschaft als Urteil. Klassen, Identitäten, Wege. Berlin, Suhrkamp.

Fuller, C (2009). Sociology, Gender and Educational Aspirations: Girls and Their Ambitions. A\&C Black. Hogben, L. (1938). Political Arithmetic: a symposium of population studies. London: Allen \& Unwin.

Jaquet, C. (2018). Zwischen den Klassen. Über die Nicht-Reproduktion sozialer Macht. Göttingen: Konstanz University Press.

Kislev, E. (2016). The effect of education policies on higher-education attainment of immigrants in Western Europe: A cross-classified multilevel analysis. Journal of European Social Policy, 26 (2), $183-199$. doi:10.1177/0958928716637142.

London, J. (1927). Martin Eden. Berlin. Büchergilde Gutenberg.

Meighan, R., \& Siraj-Blatchford, I. (1997). A Sociology of Educating. 3rd ed. Cassell, London.

Sargent, M. (1994) The New Sociology for Australians. 3rd ed. Longman Cheshire, Melbourne.

\section{Бурак Оксана}

Кандидат соціологічних наук

Інститут соціології Віденського університету

Email:Oksana.burak20@gmail.com

\section{Burak Oksana}

Candidate of Sociological Sciences

Univertsity of Vienna, Institute for Sociology

Цитування: Бурак, О. (2020). Міжкласова мобільність: життя на рубежах. Науково-теоретичний альманах «Грані», 23 (6-7), 5-13. doi: 10.15421/172060

Citation: Burak, O. (2020). Class transition: a life in between. Scientific and theoretical almanac «Grani», 23 (6-7), 5-13. doi: 10.15421/172060

Стаття надійшла / Article arrived: 03.08.2020

Схвалено до друку / Accepted: 19.08.2020 